\title{
ATTITUDE OF GENERAL PRACTITIONERS IN HEALTH SERVICE FOR CHILDREN WITH CANCER
}

\author{
Muhammad Riza'), Harsono Salimo'), Enny Listiawati²) \\ 1)Department of Child Health, Faculty of Medicine, Universitas Sebelas Maret \\ 2)Tunas Sehat Indonesia Foundation
}

\begin{abstract}
Background: Early diagnosis of cancer among children allows an opportunity for timely treatment while disease burden is still in its earliest stages. As a result, prognosis may improve, and a cure can be attained with minimal side or late effects. General practitioner has an important role to recognize the symptom and sign of disease, especially cancer. This study aimed to investigate the attitude of general practitioners in health service for children with cancer.

Subjects and Method: A descriptive study was conducted in Java, Indonesia, from June to July 2019. A total of 27 of general practitioners was selected for this study. The dependent variable was general practitioners attitude. The data were collected by questionnaire and analyzed descriptively.

Results: The lack of symptom and sign recognition of cancer in children by general practitioners and the lack of examination facilities available at the practice were the main causes of the frequent delay in the diagnosis of cancer among children. More than half of general practitioners lacked of knowledge about government program regarding registration and guidelines for early diagnosis of cancer among children.

Conclusion: The lack of symptom and sign recognition, poor examination facilities, and lack of knowledge among general practitioners are associated with the frequent delay in the diagnosis of cancer among children.
\end{abstract}

Keywords: general practitioners, cancer, children

\section{Correspondence:}

Muhammad Riza. Department of Child Health, Faculty of Medicine, Universitas Sebelas Maret, Surakarta, Central Java, Indonesia. Email: m_riza@staff.uns.ac.id. Mobile: o816679101. 